\title{
Survei Kondisi Sosial Masyarakat Dalam Memenuhi Kebutuhan Air harian di Kecamatan Minas, Kabupaten Siak
}

\author{
${ }^{1}$ Maulana Hardi, ${ }^{1}$ Yusni Ikhwan Siregar, ${ }^{2}$ Mirna Ilza, ${ }^{3}$ Sofia Anita
}

\author{
${ }^{1}$ Pascasarjana Ilmu Lingkungan Program Pascasarjana Universitas Riau, Pekanbaru, 23742 \\ ${ }^{2}$ Fakultas Perikanan dan Ilmu Kelautan Universitas Riau Kampus Bina Widya Panam KM 12.5 Pekanbaru, Telp. 0761-28293 \\ ${ }^{3}$ Fakultas FMIPA Universitas Riau Kampus Bina widya Panam KM 12.5 Pekanbaru
}

\begin{abstract}
Water is the most abundant chemical compound in nature, but in line with the increasing standard of living, the need for water also increases so that water becomes an expensive item. In some areas, it is not easy to get clean water sources that are free from pollution because high of domestic activities and water also sucked up a lot by industrial activities which require a lot of water for their production. On the other hand, land which is a water bank has been covered a lot by housing, industry, regardless of the function of the land as a vehicle for water storage. Increasing industrial and community activities can also increase the risk of pollution which can reduce the quality of existing water sources and cause difficulties for the community to meet their daily water needs. In this study, field surveys and questionnaires were conducted to obtain information about the social conditions of the community in meeting their daily water needs for drinking water and clean water. Laboratory test also conducted to evaluate the quality of water source based on regulation Peraturan Pemerintah No 82 tahun 2001. The results of the study showed that the community in Minas area still could not meet the daily water needs properly in terms of quality and quantity.
\end{abstract}

Key Words: water, survei, quisionaire, and laboratory test.

Air merupakan senyawa kimia yang paling berlimpah di alam, namun sejalan dengan meningkatnya taraf hidup manusia maka kebutuhan air pun meningkat sehingga air menjadi barang yang mahal. Di kota-kota besar tidak mudah mendapatkan sumber air bersih yang bebas dari pencemaran karena air banyak tersedot oleh kegiatan industri yang banyak memerlukan air untuk kegiatan produksinya. Di sisi lain, tanah yang merupakan celengan air sudah banyak ditutupi oleh berbagai keperluan seperti perumahan, industri, tanpa memperdulikan fungsi dari tanah tersebut sebagai wahana simpanan air. Jumlah air yang terdapat di muka bumi relatif konstan, meskipun air mengalami siklus air atau daur hidrologi yang merupakan gerakan air di bumi. Selama berlangsung berlangsungnya siklus air yaitu perjalanan air dari permukaan laut ke atmosfer kemudian ke permukaan tanah dan kembali lagi ke laut. Sirkulasi yang kontinu antara air laut dan air daratan berlangsung terus menerus dan dipengaruhi oleh kondisi meteorology (suhu, tekanan atmosfer angin, dan lainnya) dan kondisi topografi. (Susana, 2003).
Air merupakan komponen utama pada tubuh manusia. Tubuh manusia mengandung antara $60-70 \%$ air yang berfungsi menjaga suhu tubuh, memperlancar pencernaan, media transportasi gizi dan oksigen melalui peredaran darah, membantu metabolisme tubuh, memelihara kulit, dan lainnya. Menurut Sari, (2014) cairan pada tubuh manusia dibagi dalam 2 kelompok besar yaitu cairan intra seluler dan ekstra seluler. Cairan intra seluler adalah cairan yang berada di dalam sel tubuh dan cairan ekstra seluler adalah cairan yang berada di luar sel yang dibagi menjadi tiga kelompok yaitu cairan intravaskuler (plasma), cairan itesitial atau cairan yang terletak diantara sel, dan cairan intraseluler atau cairan selerasi khusus seperti cairan serebrospinal, cairan introkuler, dan sekresi saluran cerna. Kekurangan cairan ekstra seluler atau dehidrasi dapat menyebabkan gejala peningkatan frekwensi serta kontraksi jantung, pusing, mual, muntah, gangguan mental, dan lainnya.

Standar kelayakan kebutuhan air bersih adalah 49,5 liter/kapita/hari. Untuk kebutuhan tubuh manusia, air yang diperlukan adalah 2,5 
liter per hari. Standar kebutuhan air pada manusia biasanya mengikuti rumus $30 \mathrm{cc}$ per kilogram berat badan per hari. Berdasarkan Peraturan Pemerintah Nomor 14 tahun 2010 mengenai petunjuk teknis standar pelayanan minimal bidang pekerjaan umum dan tata ruang, kebutuhan minimal setiap orang akan air bersih per hari adalah 60 liter atau $0,06 \mathrm{~m} 3$ dan Direktorat Jendral Cipta Karya Departemen Pekerjaan Umum membagi lagi kebutuhan air berdasarkan lokasi wilayah sebagai berikut:

$\begin{array}{lll}\text { 1.Pedesaan dengan } & \text { kebutuhan } & 60 \\ \text { liter/orang/hari } & & \\ \text { 2.Kota kecil dengan } & \text { kebutuhan } & 90 \\ \text { liter/orang/hari } & & \\ \text { 3. Kota sedang dengan } & \text { kebutuhan } & 110 \\ \text { liter/orang/hari } & & \\ \text { 4. Kota besar dengan kebutuhan } & 130 \\ \text { liter/orang/hari } & & \\ \text { 5.Kota metropolitan dengan kebutuhan } & 150 \\ \text { liter/orang/hari } & \\ \text { Badan dunia UNESCO pada tahun } 2002\end{array}$
telah menetapkan hak dasar manusia atas air yaitu sebesar 60 liter per orang per hari (Media Tata Ruang, 2017).

Kondisi topografi Kecamatan Minas yang berada pada Kabupaten Siak terdiri dari wilayah dataran rendah dan perbukitan. Kabupaten Siak sebagian besar terdiri dari dataran rendah dengan ketinggian 0 - 50 mdpl dengan kemiringan $0^{\circ}-3^{\circ}$, sedangkan wilayah perbukitan mempunyai ketinggian antara 50 150 mdpl dengan kemiring $3^{\circ}-15^{\circ}$ (Profil Kabupaten Siak, 2013). Selain itu minimnya potensi sumber air yang dapat dimanfaatkan oleh masyarakat seperti air sungai baik secara kuantitas dan kualitas, serta belum terjangkaunya seluruh masyarakat di Kecamatan Minas oleh PDAM menambah beban masyarakan dalam memenuhi kebutuhan air harian. Berdasarkan hasil penelitian Subhan et al, (2016) menunjukan bahwa kondisi sumber air baku di Kabupaten Siak memiliki kualitas air yang kurang baik dan belum adanya kebijakan berwawasan lingkungan terkait perlindungan sumber air baku. Potensi sumber air lain untuk memenuhi kebutuhan harian masyarakat adalah penggunaan air tanah dengan menggunakan sumur bor dalam, namun pembuatan sumur ini membutuhkan sistem perizinan yang rumit serta diperlukan pemantauan khusus untuk penggunaan air sumur bor tersebut. Menurut pasal 49 ayat 1, Peraturan Pemerintah Nomor 43 Tahun 2008 Tentang Air Tanah, penetapan peruntukan air tanah harus mempertimbangkan kuantitas dan kualitas air, daya dukung akuifer terhadap pengambilan air tanah, jumlah dan sebaran penduduk serta laju pertambahannya, proyeksi kebutuhan air dan pemanfaatan air tanah yang sudah ada. Selain itu menurut pasal 67, penggunaan sumur bor ini juga harus mendapatkan izin yang diperoleh setelah memenuhi berbagai persyaratan seperti informasi peruntukan, rencana pengeboran dan Upaya Pengelolaan Lingkungan dan Pemantauan lingkungan (UKL-UPL) atau Analisis Mengenai Dampak Lingkungan (AMDAL) serta membayar retribusi sesuai dengan peraturan Perundang-undangan. Subhan et al, (2016) menyatakan bahwa selain mencakup peraturan yang telah ditetapkan, penggunaan sumur bor dalam juga harus mempertimbangkan ketersediaan Cekungan Air Tanah (CAT). Wilayah Kabupaten Siak itu sendiri terdapat beberapa kecamatan yang tidak termasuk kedalam wilayah CAT sehingga pemanfaatan air yang berasal dari sumur bor dalam tidak efektif dan efisien untuk diterapkan di wilayah ini.

Penelitian ini bertujuan untuk mendapatkan informasi mengenai profil kondisi masyarakat terkait dengan penggunaan air, informasi kualitas sumber air yang digunakan serta mendapatkan umpan balik guna perbaikan fasilitas sumber air masyarakat di Kecamatan Minas secara kualitas dan kuantitas.

\section{BAHAN DAN METODE}

\section{Metode penelitian}

Penelitian kondisi sosial masyarakat dilakukan menggunakan metode survei lapangan, kuisioner, dan kajian literatur untuk mendapatkan gambaran kondisi masyarakat seperti jenis kebutuhan air, sumber air, jumlah kebutuhan air, kemampuan, biaya yang dikeluarkan masyarakat, ketersediaan air, kualitas air, dan kasus penyakit yang disebabkan oleh penggunaan air. Dalam kuisioner juga diajukan pertanyaan untuk mendapat informasi pendukung yaitu status tempat tinggal, tingkat pendidikan, jenis pekerjaan, dan penghasilan masyarakat. 
Survei lapangan juga menyertakan wawancara untuk mengidentifikasikan adanya umpan balik (feedback) atau keluhan (complain) terhadap sumber air atau kondisi sosial masyarakat di Kecamatan Minas yang mencakup:

1. Kualitas air yang digunakan

2. Kuantitas (ketersediaan) sumber air

3. Dampak kesehatan atau penyakit

4. Biaya untuk memenuhi kebutuhan air

Pada penelitian ini juga dilakukan pengujian laboratorim untuk contoh air dari sumber air yang digunakan oleh masyarakat untuk semua parameter uji yang disyaratkan pada Peraturan Pemerintah No. 82 Tahun 2001 tentang Pengelolaan Kualitas Air dan Pengendalian Pencemaran Air kecuali parameter parameter oksigen terlarut (DO), fecal dan total coliform, parameter radioaktif gross alfa dan beta. Pengujian laboratorium untuk karakteristik kimia dilakukan di laboratorium yang terakreditasi ISO 17025 untuk memastikan kehandalan data dari sisi akurasi dan presisi serta untuk mendapatkan data yang representatif. Laboratorium terakreditasi ini akan melakukan pengujian menggunakan metode standar nasional (SNI) dan standar international termutakhir seperti EPA, APHA, ASTM, atau metode pengujian lainnya yang terbukti validitasnya secara ISO 17025 .

\section{Alat dan bahan}

Alat dan bahan yang digunakan dalam penelitian ini adalah: peralatan survei (alat pencatat/perekam), kamera, daftar pertanyaan atau kuesioner, keterangan atau informasi masyarakat, dan aplikasi pengolahan data (excel worksheet).

Untuk uji laboratorium digunakan peralatan pengujian laboratorium seperti peralatan Sampling air, peralatan uji laboratorium yaitu Spektrofotometer $\mathrm{HACH}$ 2800, Gas Chromatography Agilent (GC-FID) 7890, Ion Chromatography DIONEX ICS 3000, $\mathrm{pH} /$ Conductivity meter HACH HQ40, Inductively Couple Plasma (ICP-OES) Perkin Elmer 8300DV, mercury analyzer LUMEX, peralatan gelas, timbangan analitis, dan alat penunjang untuk perparasi contoh air. Untuk bahan kimia digunakan larutan pengujian seperti larutan standar, larutan jaminan mutu (QC), larutan pereaksi yang diproduksi oleh $\mathrm{HACH}$, Fischer, MERCK, dan air destilat.

\section{Pengambilan sampel}

Pelaksanaan survei dan kunjungan lapangan dilakukan pada masyarakat yang tinggal di Kecamatan Minas. Kegiatan survei dan kuisioner dilakukan pada akhir pekan atau hari libur untuk mendapatkan informasi dari kepala keluarga secara langsung.

Untuk pengambilan contoh air masyarakat dilakukan pengulangan sebanyak 3 kali dalam waktu 3 bulan lokasi yang sama. Teknik pengambilan contoh air menggunakan Standard Method APHA SM 1060 dan dilakukan pengiriman ke laboratorium pada hari yang sama dan dilakukan analisa dalam masa holding time contoh air untuk masing-masing parameter pengujian.

\section{HASIL}

Survei lapangan dilakukan pada hari Sabtu dan Minggu tanggal 8-9 Desember 2018, jam 10.00 hingga jam 15.00 untuk mendapatkan informasi karakter atau kondisi sosial masyarakat dalam hal penggunaan air untuk kebutuhan harian. Kunjungan dan kuisioner ini melibatkan 30 responden dengan 16 responden memberikan jawaban lengkap, 4 responden dengan jawaban dengan lengkap dan 10 responden tidak bersedia untuk berpartisipasi. Hasil kuisioner kondisi sosial masyarakat terdapat terdapat pada Tabel 1 dan untuk umpan balik (feedback) untuk sumber air masyarakat terdapat pada Tabel 2. Analisis untuk data kuisioner dilakukan hanya untuk responden yang memberikan jawaban lengkap.

Hasil pengujian laboratorium untuk kualitas sumber air masyarakat menunjukan masih ada beberapa parameter uji yang tidak memenuhi persyaratan yang telah ditetapkan pada Peraturan Pemerintah No 82 tahun 2001. Hasil pengujian kualitas air depot isi ulang menunjukan parameter yang melampaui batas baku mutu adalah logam selenium, nitrat, dan MBAS. Hasil pengujian laboratorium untuk air PDAM menunjukan nilai $\mathrm{pH}$ dan logam besi mempunyai nilai yang melampaui baku mutu dan untuk air sumur parameter yang melampaui baku mutu adalah logam selenium, belerang dan nitrat, sedangkan untuk air dari penjual keliling tidak ada parameter yang melampaui baku 
mutu. Hasil pengujian laboratorium dapat dilihat pada Tabel 3 hingga Tabel 5.

Tabel 1. Hasil jawaban kuisioner kondisi sosial masyarakat dalam memenuhi kebutuhan air harian

\begin{tabular}{|c|c|c|c|c|}
\hline \multirow{2}{*}{$\begin{array}{l}\text { Pertanyaan } \\
\text { Status tempat tinggal }\end{array}$} & \multicolumn{4}{|c|}{ Jawaban kuisioner dan persentase } \\
\hline & Milik Sendiri & Milik Keluarga & Kontrak/sewa & lainnya \\
\hline & $75 \%$ & $6 \%$ & $19 \%$ & - \\
\hline \multirow[t]{2}{*}{ Latar belakang pendidikan } & Tidak Sekolah & SD & SMA & PT \\
\hline & - & $37 \%$ & $50 \%$ & $13 \%$ \\
\hline \multirow[t]{2}{*}{ Jenis pekerjaan } & PNS & Peg. Swasta & Usaha & Tidak Kerja \\
\hline & $6 \%$ & $19 \%$ & $75 \%$ & - \\
\hline \multirow[t]{2}{*}{ Penghasilan per bulan } & $<1$ juta & $1,2-2,5$ juta & 2,5-5 juta & $>5$ juta \\
\hline & $19 \%$ & $3 \%$ & $44 \%$ & $13 \%$ \\
\hline \multirow[t]{2}{*}{ Sumber air bersih masyarakat } & Sumur & PAM & Penyalur & Lainnya \\
\hline & $28 \%$ & $31 \%$ & $31 \%$ & - \\
\hline \multirow[t]{2}{*}{ Kualitas air bersih } & Sangat baik & baik & Kurang baik & Tidak baik \\
\hline & $6 \%$ & $56 \%$ & $31 \%$ & $6 \%$ \\
\hline \multirow[t]{2}{*}{ Sumber air minum } & Sumur & Depot isi ulang & PAM & Penyalur \\
\hline & $19 \%$ & $81 \%$ & - & - \\
\hline \multirow[t]{2}{*}{ Biaya kebutuhan air per hari } & $<10$ ribu & 10-50 ribu & 50-100 ribu & $>100$ ribu \\
\hline & $38 \%$ & $50 \%$ & $6 \%$ & $6 \%$ \\
\hline \multirow[t]{2}{*}{ Kesulitan air bersih } & Tidak pernah & $1-5$ kali & 5-10 kali & $>10$ kali \\
\hline & $43 \%$ & $13 \%$ & $31 \%$ & $13 \%$ \\
\hline \multirow[t]{2}{*}{ Riwayat penyakit karena air } & Tidak pernah & 1-2 kali & 3-5 kali & $>5$ kali \\
\hline & $88 \%$ & $12 \%$ & - & - \\
\hline
\end{tabular}

Tabel 2. Identifikasi umpan balik (feedback) atau keluhan (complain) terhadap sumber air masyarakat

\begin{tabular}{|c|c|c|c|c|c|c|c|c|}
\hline \multirow[t]{3}{*}{ Parameter } & \multicolumn{2}{|c|}{ Isi Ulang } & \multicolumn{2}{|c|}{ Sumur } & \multicolumn{2}{|c|}{ PDAM } & \multicolumn{2}{|c|}{ Penjual Keliling } \\
\hline & Air & Air & Air & Air & Air & Air & Air & Air Bersih \\
\hline & Minum & Bersih & Minum & Bersih & Minum & Bersih & Minum & \\
\hline Pengguna Air & ada & tidak & ada & ada & tidak & ada & tidak & ada \\
\hline Keluhan & tidak & - & tidak & ada & - & ada & - & tidak \\
\hline kualitas & & & & & & & & \\
\hline Keluhan & tidak & - & ada & ada & - & ada & - & tidak \\
\hline Ketersediaan & & & & & & & & \\
\hline $\begin{array}{l}\text { Keluhan } \\
\text { penyakit }\end{array}$ & tidak & - & tidak & tidak & - & ada & - & tidak \\
\hline Keluhan biaya & tidak & - & ada & ada & - & ada & - & ada \\
\hline
\end{tabular}


Tabel 3. Parameter uji melampaui batas baku mutu untuk air depot isi ulang

\begin{tabular}{cccccccccc}
\hline & Parameter & Unit & \multicolumn{2}{c}{ Baku Mutu } & \multicolumn{3}{c}{ Konsentrasi } & n & s \\
& & & I & II & Terendah & Tertinggi & Rerata & \\
\hline 1. & Selenium & $\mathrm{mg} / \mathrm{L}$ & 0,01 & 0,05 & 0,02 & 0,03 & 0,02 & 3 & 0,01 \\
2. & Nitrat & $\mathrm{mg} / \mathrm{L}$ & 10 & 10 & 8,60 & 13,40 & 11,02 & 3 & 2,40 \\
3. & MBAS & $\mathrm{mg} / \mathrm{L}$ & 0,2 & 0,2 & 0,18 & 0,51 & 0,32 & 3 & 0,17 \\
\hline
\end{tabular}

Tabel 4. Parameter uji melampaui batas baku mutu air PDAM

\begin{tabular}{|c|c|c|c|c|c|c|c|c|c|}
\hline \multirow[t]{2}{*}{ No. } & \multirow[t]{2}{*}{ Parameter } & \multirow[t]{2}{*}{ Unit } & \multicolumn{2}{|c|}{ Baku Mutu } & \multicolumn{3}{|c|}{ Konsentrasi } & \multirow[t]{2}{*}{$\mathrm{n}$} & \multirow[t]{2}{*}{$\mathbf{s}$} \\
\hline & & & I & II & Terendah & Tertinggi & Rerata & & \\
\hline 1. & $\mathrm{pH}$ & - & $6-9$ & $6-9$ & 4,0 & 5,20 & 4,60 & 3 & 0,60 \\
\hline 2. & Besi & $\mathrm{mg} / \mathrm{L}$ & 0,3 & - & 0,9 & 1,20 & 1,00 & 3 & 0,15 \\
\hline
\end{tabular}

Tabel 5. Parameter uji melampaui batas baku mutu untuk air sumur masyarakat

\begin{tabular}{|c|c|c|c|c|c|c|c|c|c|}
\hline & \multirow[t]{2}{*}{ Parameter } & \multirow[t]{2}{*}{ Unit } & \multicolumn{2}{|c|}{ Baku Mutu } & \multicolumn{3}{|c|}{ Konsentrasi } & \multirow[t]{2}{*}{$\mathbf{n}$} & \multirow[t]{2}{*}{$\mathbf{s}$} \\
\hline & & & I & II & Terendah & Tertinggi & Rerata & & \\
\hline 1. & Selenium & $\mathrm{mg} / \mathrm{L}$ & 0,01 & 0,05 & 0,02 & 0,03 & 0,02 & 3 & 0,01 \\
\hline 2. & Belerang & $\mathrm{mg} / \mathrm{L}$ & 0,002 & 0,002 & 0,02 & 0,03 & 0,02 & 3 & 0,01 \\
\hline 3. & Nitrat & $\mathrm{mg} / \mathrm{L}$ & 10 & 10 & 20,40 & 23,50 & 21,96 & 3 & 1,50 \\
\hline
\end{tabular}

n: jumlah data, s: standar deviasi

\section{PEMBAHASAN}

Pertanyaan pada bagian pertama kuisioner adalah tentang status rumah tinggal responden untuk memastikan informasi yang didapat dari survei dapat mewakili kondisi masyarakat Kecamatan Minas. Hasil jawaban responden, masyarakat yang milik sendiri sebanyak $75 \%$; milik keluarga sebanyak 6\%; dan masyarakat yang melakukan sewa atau kontrak sebanyak 19\%. Dari hasil kuisioner menunjukan bahwa sebagian besar responden adalah masyarakat asli atau masyarakat yang sudah lama menetap dan sudah menjadi warga di Kecamatan Minas.

pertanyaan selanjutnya adalah tentang tingkat pendidikan masyarakat dan didapat informasi pendidikan responden adalah lulusan SD-SMP sebanyak 38\%, lulusan SMA sebanyak $50 \%$, dan lulusan perguruan tinggi sebanyak $13 \%$. Tingkat Pendidikan masyarakat dapat dihubungkan dengan tingkat pengetahuan masyarakat tentang fasilitas atau teknologi pengolahan air serta kelayakan atau kualitas air yang dapat digunakan untuk memenuhi kebutuhan air harian. Dari jawaban kuisioner didapat sebagian besar responden memiliki tingkat pendidikan tertinggi SMA dan hanya sebagian kecil yang mempunyai tingkat latar belakang perguruan tinggi. Hal sesuai dengan pengamatan di lapangan yaitu saat ini masyarakat secara individual tidak ada yang menggunakan teknologi pengolahan air yang dapat disebabkan minimnya pengetahuan tentang teknologi pengolahan air sehingga hanya memanfaatkan sumber air yang sudah ada di wilayah sekitar tempat tinggal.

Selanjutnya untuk jenis pekerjaan, sebagian besar responden menyebutkan melakukan usaha sebanyak $75 \%$ sebagai mata pencarian utama. Dari pertanyaan berikutnya untuk jenis usaha, sebanyak 50\% responden menjawab melakukan usaha dagang dan sebanyak $50 \%$ responden lainnya menjawab usaha perkebunan serta tidak ada responden yang menjawab usaha perikanan sebagai jenis usaha yang dilakukan. Hasil survei 
ini sesuai dengan pengamatan yang dilakukan bahwa sebagian besar masyarakat tinggal di daerah yang dikelilingi oleh perkebunan sawit dan responden yang mempunyai usaha perdagangan umumnya adalah masyarakat yang tinggal di daerah pusat wilayah Minas yang terdapat sebuah pasar kecamatan.

Pertanyaam mengenai penghasilan responden perbulan didapat informasi penghasilan dibawah Rp. 1 juta sebesar 19\%, masyarakat dengan penghasilan Rp. 1-2,5 juta sebesar $3 \%$, masyarakat dengan penghasilan Rp. 2,5-5 juta sebesar 44\%, masyarakat dengan penghasilan di atas Rp. 5 juta sebesar $13 \%$ dan masyarakat yang tidak menjawab sebesar $11 \%$. Dari informasi yang didapat menunjukan sebagian besar dari masyarakat memiliki penghasilan di atas upah minimum Provinsi Riau sebesar Rp. 2,5 juta namun masih terdapat masyarakat yang memiliki penghasilan di bawah UMR sebesar 22\%. Informasi ini menunjukan bahwa masih ada masyarakat yang memiliki kemampuan ekonomi yang rendah yang dapat mengalami kesulitan dalam memenuhi kebutuhan air harian.

Pertanyaan kuisioner selamjutnya adalah pertanyaan terkait dengan penggunaan air masyarakat. Pertanyaan pertama yaitu mengenai sumber air yang digunakan oleh masyarakat. Dari survei lapangan diketahui beberapa sumber air bersih yang digunakan untuk memenuhi kebutuhan harian masyarakat harian antara lain air sumur, air PDAM, dan air dari penyalur keliling. Dari jawaban responden didapat yang menggunakan air sumur sebesar 28\%, perusahaan daerah air minum (PDAM) sebesar $31 \%$, dan penyalur air keliling sebesar $31 \%$. Untuk responden yang menggunakan air yang dari perusahaan daerah air minum (PDAM) adalah responden yang tinggal di wilayah pusat kecamatan yang terjangkau fasilitas PDAM, sedangkan responden yang menggunakan air dari penyalur keliling adalah responden yang tidak terjangkau pipa distribusi PDAM dan tidak memiliki sumur air pribadi.

Pertanyaan pada kuisioner selanjutnya adalah sumber air minum yang digunakan di Kecamatan Minas, responden yang menggunakan air minum depot isi ulang sebesar $81 \%$ dan sisanya menggunakan air sumur sebesar $19 \%$. Hasil wawancara memberikan informasi tidak ada responden yang menggunakan air PDAM karena meragukan kualitasnya untuk dapat digunakan sebagai air minum dan masyarakat juga tidak menggunakan air dari penyalur keliling karena air tersebut masih harus dimasak untuk dapat diminum. Dari hasil wawancara juga didapat informasi sebagian besar responden merasa tidak mempunyai banyak pilihan sehingga menjadikan air minum depot isi ulang sebagai sumber air minum utama karena dipercayai telah diolah dengan teknologi yang tinggi dan mempunyai harga yang terjangkau dibandingkan dengan membeli air minum galon yang bermerek. Namun demikian masih ada beberapa responden yang meragukan kualitas air minum depot isi ulang yang digunakan.

Pada pertanyaan biaya yang dikeluarkan masyarakat untuk memenuhi kebutuhan air harian (air minum dan air bersih), masyarakat yang mengelurkan biaya kurang dari 10 ribu rupiah adalah sebesar $38 \%$. Masyarakat yang mengeluarkan biaya 10 ribu hingga 50 ribu rupiah perhari sebesar $50 \%$. Masyarakat yang mengeluarkan biaya 50 ribu hingga 100 ribu rupiah sebesar $6 \%$. Biaya yang besar umumnya dikeluarkan oleh responden yang menggunakan air dari penyalur keliling dengan harga 30 ribu hingga 60 ribu per tycoon (1000 liter) dan sebagian besar keluarga membutuhkan 2 tycoon per minggu sehingga biaya yang harus dikeluarkan dalam sebulan dapat mencapai 400 ribu rupiah untuk air bersih dan belum termasuk biaya untuk air minum apabila menggunakan air minum depot isi ulang.

Pada pertanyaan kuisioner berikutnya mengenai kesulitan untuk mendapatkan air bersih untuk kebutuhan harian dalam setahun sebanyak $44 \%$ responden menjawab tidak pernah ada kesulitan, sedangkan responden lainnya menjawab pernah mengalami kesulitan 1-5 kali sebesar $13 \%$, responden yang pernah mengalami kesulitan 5-10 kali sebesar 30\%, dan responden yang pernah mengalami kesulitan lebih dari 10 kali sebesar $13 \%$ maka total masyarakat yang mengalami kesulitan adalah sebanyak 56\%. Hasil wawancara memberikan informasi responden yang mempunyai kesulitan dalam mendapatkan air bersih adalah responden yang menggunakan air PDAM pada musim kemarau saat pasokan air ke PDAM sangat terbatas bahkan pernah tidak ada pasokan air ke masyarakat untuk beberapa 
hari. Selain pada musim kemarau, kesulitan air juga dirasakan responden pelanggan PDAM pada musim hujan karena kualitas air yang dipasok terkadang berwarna keruh atau tidak layak untuk digunakan.

Pertanyaan survei terakhir mengenai riwayat masalah kesehatan yang pernah diderita akibat penggunaan air, responden yang menjawab tidak pernah ada masalah kesehatan sebanyak $88 \%$ dan sebanyak $12 \%$ pernah mengalami masalah kesehatan akibat kualitas air yang tidak baik. Hasil wawancara didapat informasi masalah kesehatan yang pernah dialami masyarakat adalah gatal-gatal pada kulit yang diakibatkan oleh penggunaan air yang berasal dari PDAM. Penyakit gatal pada kulit akibat penggunaan air PDAM sangat memungkinkan mengingat hasil pengujian laboratorium air bersifat asam dengan $\mathrm{pH} 4,6$. Penggunaan air yang besifat asam ini selain berbahaya bagi kulit juga sangat berbahaya apabila dikonsumsi untuk air minum yang dapat menyebabkan kerusakan pada sistem pencernaan. Hal lain yang juga berbahaya adalah sifat asam dari air akan mudah melarutkan logam berbahaya bila dikonsumsi dapat menyebabkan kerusakan organ ginjal.

Pada kegiatan survei dan wawancara juga dilakukan pengumpulan adanya keluhan masyarakat atau umpan balik (feedback) untuk kualitas air yang ada di masyarakat sehingga dapat dilakukan analisa komparasi kualitas sumber air. Komparasi kualitas sumber air ini juga bertujuan untuk memberikan informasi sumber air air yang terbaik dan juga saran perbaikan untuk memenuhi kebutuhan air masyarakat. Hasil identifikasi adanya umpan balik atau keluhan untuk sumber air masyarakat dapat dilihat pada Tabel 2. Untuk kebutuhan air minum, analisis dilakukan berdasarkan umpan balik dari pengguna air sumur dan air minum isi ulang karena tidak ada informasi masyarakat menggunakan air PDAM dan air penyalur

keliling untuk air minum. Sedangkan untuk air bersih, komparasi dilakukan untuk air sumur, air PDAM dan air penyalur keliling. Air depot isi ulang tidak disertakan karena tidak ada informasi ada masyarakat yang menggunakan air minum depot isi ulang untuk kebutuhan air bersih harian.

Hasil survei dan wawancara masyarakat untuk penggunaan air minum dan air bersih terdapat umpan balik atau keluhan dari masyarakat untuk setiap sumber air yang digunakan di Kecamatan Minas kecuali air penjual keliling yang sumbernya berasal dari luar Kecamatan Minas. Air bersih PDAM paling banyak mendapatkan umpan balik dari masyarakat untuk prihal kualitas dan ketersedian air untuk masyarakat. Hasil dari pengujian laboratorium untuk sumber air masyarakat menunjukan adanya beberapa parameter melampaui baku mutu yang disyaratkan yang dapat menyebabkan masalah kesehatan apabila sumber air tersebut dikonsumsi untuk kebutuhan harian masyarakat.

\section{KESIMPULAN}

Berdasarkan hasil studi yang dilakukan melalui survei masyarakat, kuisioner, dan pengujian laboratorium untuk contoh air yang digunakan oleh masyarakat, didapat informasi bahwa masyarakat di Kecamatan Minas belum dapat memenuhi kebutuhan air harian secara layak. Masyarakat di Kecamatan Minas memerlukan sumber air baru untuk memenuhi kebutuhan masyarakat secara kuantitas dan memerlukan peningkatan atau perbaikan fasilitas pengolahan air untuk memenuhi persyaratan kualitas air minum dan air bersih.

\section{DAFTAR PUSTAKA}

Media Tata Ruang, 2017. Standar kebutuhan air menurut WHO. http://mediatataruang.com.

Profil Daerah Kabupaten Siak 2013, BAPPDA Kabuptem Siak, 2014.

Sari, I.P.T.P. 2014. Tingkat pengetahuan tentang pentingnya mengkonsumsi air mineral pada siswa kelas IV di SD Negeri Keputran Yogyakarta. Jurnal Pendidikan Jasmani Indonesia 10(2):55-61.

Susana, T. 2003. Air sebagai sumber kehidupan. Jurnal Oseana 17(3):17-25.

Subhan, D. U.M. Tang. F. Fatnanta. 2016. Strategi pemanfaatan sumber air di Kabupaten Siak untuk pengembangan unit pelayanan teknis daerah (UPTD) air minum kabupaten Siak. Jurnal Photon 7(1):11-18. 